\title{
Micro-film edition of Africa
}

ARRANGEMENTs have been made for the micro-filming of Africa in order to make it available to libraries, \&c. in this considerably reduced form, thus facilitating filing and subsequent reference. The Micro editions, which will include volumes covering the period I928-58, will be issued by Micro Methods Limited of East Ardsley, Wakefield, Yorkshire, to whom all applications for further information should be made. The cost of one complete volume will be $£ 3$ per annum, and the complete set ( 3 I years) will be available at $£ 90$. (Single issues cannot be supplied.)

\section{'The African Explains Witchcraft': a Correction}

WE are grateful to Mr. J. Lewton Brain for pointing out an error in "The African Explains Witchcraft' which appeared in Africa, October 1935. The text given on pp. 504-7 under the heading 'Nuer' is not Nuer but Acoli. Mr. Lewton Brain confirmed this with the author, Fr. J. P. Crazzolara, who told him that the error arose through a misunderstanding by Professor Westermann, who was then Editor of Africa.

\section{El Instituto Claretiano de Africanistas}

ThIs Institute, founded recently in Santa Isabel, Fernando Po, is under the patronage of the religious order of the Misioneros Claretianos. Its object is to collect material and provide assistance for persons interested in the culture of Spanish Guinea and of Africa in general. The Institute has an Africanist library, which already contains 3,000 volumes, and a museum. It publishes the monthly review La Guinea Española and two small monthlies in the Bubi and Fang languages.

\section{Population Movements and Malaria Eradication}

Schemes for the control and eradication of malaria, sponsored by the World Health Organization, are being hampered by the contacts between areas from which malaria has been cleared and those which, because of the movement of peoples, remain malarious. The sixth report of the Expert Committee on Malaria of the WHO (1957) stated that mass movements of population in the malaria season are likely to exacerbate the disease.

More information is needed on the pattern, scale, and causes of these movements and the extent to which they can be controlled. The Planning Division for Malaria Eradication of the WHO have accordingly asked R. Mansell Prothero of the Department of Geography, University of Liverpool, and formerly of University College, Ibadan, and the West African Institute of Social and Economic Research, to prepare a report on existing information relating to movements of population in Africa South of the Sahara. A similar report is to be prepared for the Middle and Far East. The report will cover nomadic pastoral, migrant labour, and pilgrim movements. Though information and data are incomplete, it should be possible to assemble and analyse a body of worthwhile material.

Mr. Prothero will be travelling in Africa as a consultant of the WHO during the first six months of 1960 for discussions with officials and research workers in the social sciences. He will be grateful to hear of published or unpublished material relevant to his work. Information should be addressed to him, c/o the Department of Geography, 2 Abercromby Square, Liverpool 7 .

$$
\text { [Communicated by R. Mansell Prothero] }
$$

\section{Study Group on Asian and African Languages}

A REPORT of the Study Group on Asian and African Languages, initiated by the N.A.T.O. Parliamentarians, Conference of 1958, held from 25 to 29 May 1959, has been issued by the 